ARQGA/1201

\title{
EXPRESSION OF THE p53 PROTEIN AND CLINICAL AND PATHOLOGIC CORRELATION IN ADENOCARCINOMA OF THE RECTUM
}

\author{
Márcia Teresinha JURACH, Luise MEURER and Luis Fernando MOREIRA
}

ABSTRACT - Background - p53 is a tumor suppressor gene that has been implicated in the pathogenesis of a wide range of tumors, including colorectal cancer. Aim - To evaluate the prognostic significance of p53 protein expression, and to correlate with clinical and pathologic variables as well as survival. Patients and Methods - Immunohistochemical staining for p53 protein was performed in a series of 83 patients with rectal cancer with a follow-up of at least 5 years. Results - Expression of nuclear protein was positive in 36 (43.4\%) of the tumors. We found association between positive p53 and death, local recurrence, distant metastasis and overall recurrence and we also found association between p53 and death, local recurrence, metastasis and overall recurrence when analysis was adjusted to Astler-Coller stage and grade of differentiation. Conclusion - p53 immunoexpression has shown to be an independent prognostic factor in these series.

HEADINGS - Protein p53. Rectal neoplasms. Adenocarcinoma.

\section{INTRODUCTION}

Colorectal cancer is a frequent tumor in western world and it has been increasing its incidence over the past decades ${ }^{(1)}$. It remains as a great source of morbidity and mortality, despite improvement on early diagnosis, surveillance procedures for high risk individuals, surgical techniques and adjuvant treatment ${ }^{(5,10,12,17)}$.

The biologic and clinic behavior of rectal tumor has not been entirely clarified. Although its prognosis is related to the histopathologic aspects such as invasion into the rectal wall or perirectal fat and lymph node involvement, patients with tumors at early stages and operated with a curative intention, may present an undesirable outcome and on the other hand far advanced tumors may do well ${ }^{(1,10,12,18,23)}$.

New prognostic factors have been studied to better clarify these unpredictable outcomes, including genetic alteration and cell cycle control mechanisms. The establishing of a correlation between genetic damage and prognosis has been the goal of extensive investigations in the last few years, as well as the mechanisms of the cell cycle $^{(18,25)}$. p53 is a tumor suppressor gene, located in the short arm of chromosome 17 and produces a protein named $\mathrm{p} 53^{(2,14)}$. Its primary function is to control checkpoints at the cell cycle, to promote DNA repair by stimulating other proteins (pRb, p21) and to stimulate apoptosis. Mutations of this gene produce an inactive p53 protein, which accumulates in the tumor cells. The expression of this altered protein is detected in $30 \%$ to $70 \%$ of rectal tumors and may be related to poor prognosis ${ }^{(2,14)}$.

This study describes the correlation between p53 protein immunoexpression and clinical and pathologic factors, survival rates and prognosis.

\section{PATIENTS AND METHODS}

We evaluated 83 patients with rectal adenocarcinoma submitted to potentially curative surgery at Coloproctology Unit of the "Hospital de Clínicas de Porto Alegre" (HCPA), Porto Alegre, RS, Brazil, from 1985 to 1997.

The clinical and pathologic data was carefully obtained from patient charts through retrospective assessment of the clinical follow-up notes, their respective diagnostic exams and anatomic or pathologic exams of the surgical

This work was partially granted by CAPES - PRODOC -2002 .

Department of Surgery, Federal University of Rio Grande do Sul, Porto Alegre, RS, Brazil.

Address for correspondence: Dr. Luis Fernando Moreira - Programa de Pós-Graduação em Cirurgia -Faculdade de Medicina - UFRGS - Rua Ramiro Barcelos, 2400 - $2^{\circ}$ andar, sala 247 - 90035-003 Porto Alegre, RS, Brazil. E-mail: bruce@cpovo.net 
specimens. The stage of the tumor was defined according to the Astler-Coller classification.

The studied variables were age, gender, tumor location, symptoms, type of the surgical procedure, staging, number of metastatic lymph nodes, survival rates, disease-free intervals, tumor aspect and size, neoplasiafree distal margin, loco-regional recurrence and metastasis.

The p53 immunostaining was performed on surgical specimens of 83 patients with rectal adenocarcinoma. The p53 evaluation by the immunostaining technique (IHC) used specific antibodies, anti-p53 human (Pab-1801) and its expression was classified according to the percentage of positive nuclei. For positive p53, a cutoff value of $20 \%$ was considered, in other words, when more than $20 \%$ of nuclei stained in a microscopic field magnified $400 \mathrm{X}$. The preparation of the slides (IHC and hematoxylin-eosin) and their assessment were performed by the Pathology Unit of the HCPA, using the formaline-fixed paraffin-embedded blocks from the surgical specimens, and analyzed by two independent pathologists with experience in gastrointestinal pathology.

\section{Antibody}

The primary antibody used was a mouse mononuclear antibody Pab-1801 (Sigma Biosciences, St Louis, MO, USA) which recognizes both wild type and mutant human $\mathrm{p} 53$, but given the extremely short half-life of the wild type protein, staining is likely to represent abnormal accumulation of the mutant type only.

\section{Immunostaining technique}

Samples of tumor tissues were processed for $\mathrm{p} 53$ protein expression as a routine immunostaining technique at our hospital, using the primary antibody previously described. After dewaxing, rehydration and antigen recovery, inactivating endogenous peroxidase activity, and blocking cross-reaction with normal serum, the sections were incubated for 12 hours at $4^{\circ} \mathrm{C}$ with a solution of the primary antibody diluted at 1:100. Identification of the primary antibody site was achieved by subsequent application of biotinylated antibody, streptavidin horseradish peroxidase conjugate (LSAB, Dako) and its reaction by the use of diamino-benzidine tetrahydrochloride as chromogen (Kit DAB, Dako). The control staining of the slides was performed with Harris hematoxylin. All the immunostaining section had positive (breast cancer) and negative (absence of primary antibody) controls.

\section{Statistical analysis}

The quantitative data were described as average and standard deviation (SD). For categoric variables, absolute and percentage frequencies were used. Overall survival and disease-free interval were initially calculated by Kaplan-Meyer curves. The bivariate association between outcomes of interest and patient characteristics, including determination of the $\mathrm{p} 53$, as evaluated by relative risk $(\mathrm{RR})$, confidence interval (CI), and their significance by Chi-square test. The simultaneous influence or multiple variables over mortality, local recurrence and metastasis was evaluated by Cox's regression method, obtaining the adjusted relative risks and their respective confidence intervals. The level of significance in the bivariate analysis was $P=0.05$, and in the multivariate regression analysis was $P=0.10$. The data were processed and analyzed in a SPSS version 10.0 software.

\section{RESULTS}

We studied 83 cases of rectal adenocarcinoma; $47 \%$ of them (39) were male. The mean (SD) age at the time of the operation was $61.8(\mathrm{SD}=14.3)$ years. The most frequent symptoms were bleeding, diarrhea, constipation, anal pain and an average weight loss of $9.4 \mathrm{~kg}$. These symptoms were referred in an average of 9 months prior to the diagnosis.

Considering the tumor site, $48 \%$ were located in the lower rectum, $34 \%$ in the middle rectum and $18 \%$ in the upper rectum. The mean (SD) distance between the tumor and the anal verge was $7(3.9) \mathrm{cm}$. The surgical procedures performed consisted of Miles operation in 42 patients; low anterior resection with manual anastomosis in 21 patients; stapled anastomosis in 11, coloanal anastomosis in 3 and Hartmann's procedure in 6 patients. Table 1 shows the clinical and pathologic characteristics of the patients included in the study. The distal margin could be analyzed in 41 (49\%) cases. The other 42 cases underwent rectal amputation. The tumor macroscopic appearance was considered elevated, infiltrating or ulcerated, but in most of the cases showed an association between two or the three forms. The exophitic appearance of the lesion was demonstrated in $82.4 \%$ of the cases. In eight cases the appearance was unclear.

The staging classification used was the Astler-Coller (Duke's modified classification, 1954). Since there was no patient in stage A, all cases were divided into four categories only: B1, B2, C1 and $\mathrm{C} 2$, as shown in Table 1.

TABLE 1 - Clinical and pathologic characteristics of the patients

\begin{tabular}{lcc}
\hline Characteristics & $\mathbf{n}$ & Description \\
\hline Age, years (mean) & 83 & $61.8(14.3)$ \\
Male gender & 83 & $39(47.0)$ \\
Distance from the anal verge $(\mathrm{cm})$ & 83 & $7.0(3.9)$ \\
Distal limit $(\mathrm{cm})$ & 43 & $2.3(1.5)$ \\
Tumor size $(\mathrm{cm})$ & 73 & $5.5(2.0)$ \\
Macroscopic appearance & 75 & $59(78.7)$ \\
Ulcerated & & $23(27.7$ \\
Infiltrating & & $61(82.4)$ \\
Exophitic & 83 & $21(25.3)$ \\
Astler-Coller classification & & $16(19.3)$ \\
B1 & & $10(12.0)$ \\
B2 & & $36(43.4)$ \\
C1 & 83 & $11(13.3)$ \\
C2 & & $61(73.5)$ \\
Grade of differentiation & $11(13.3)$ \\
Well differentiated & \\
Moderately differentiated & \\
Undifferentiated & & \\
\hline Figures are presented as average and standard deviation of frequency &
\end{tabular}

The mean number of lymph nodes examined on each surgical specimen was $15.4(9.2)$ and the average of positive lymph nodes was 5.6.

Out of the 83 cases examined, 36 patients $(43.4 \%)$ presented tumor recurrence; $13(16 \%)$, local recurrence; 17 patients $(20 \%)$, distant metastasis and 6 patients $(7 \%)$ presented both local recurrence and distant metastasis. In Table 2, the site of metastasis during the 60 months follow-up is shown. 
TABLE 2 - Sites of metastasis presented by the patients

\begin{tabular}{lcc}
\hline Site & $\mathbf{n}$ & Local recurrence* \\
\hline Liver & 9 & $(1)$ \\
Lungs & 5 & $(1)$ \\
Bones & 2 & $(1)$ \\
Bones + lungs & 3 & $(1)$ \\
Liver + lungs & 3 & $(1)$ \\
Axillary + lungs & 1 & $(1)$ \\
Total & 23 & $(6)$ \\
\hline * Synchronous cases of associated local recurrence & &
\end{tabular}

The survival rates were calculated in relation to the disease-free interval and overall survival according to the Kaplan-Meyer method and are displayed in Figure 1. The mean (SD) disease-free interval was 17 (10.6) months.

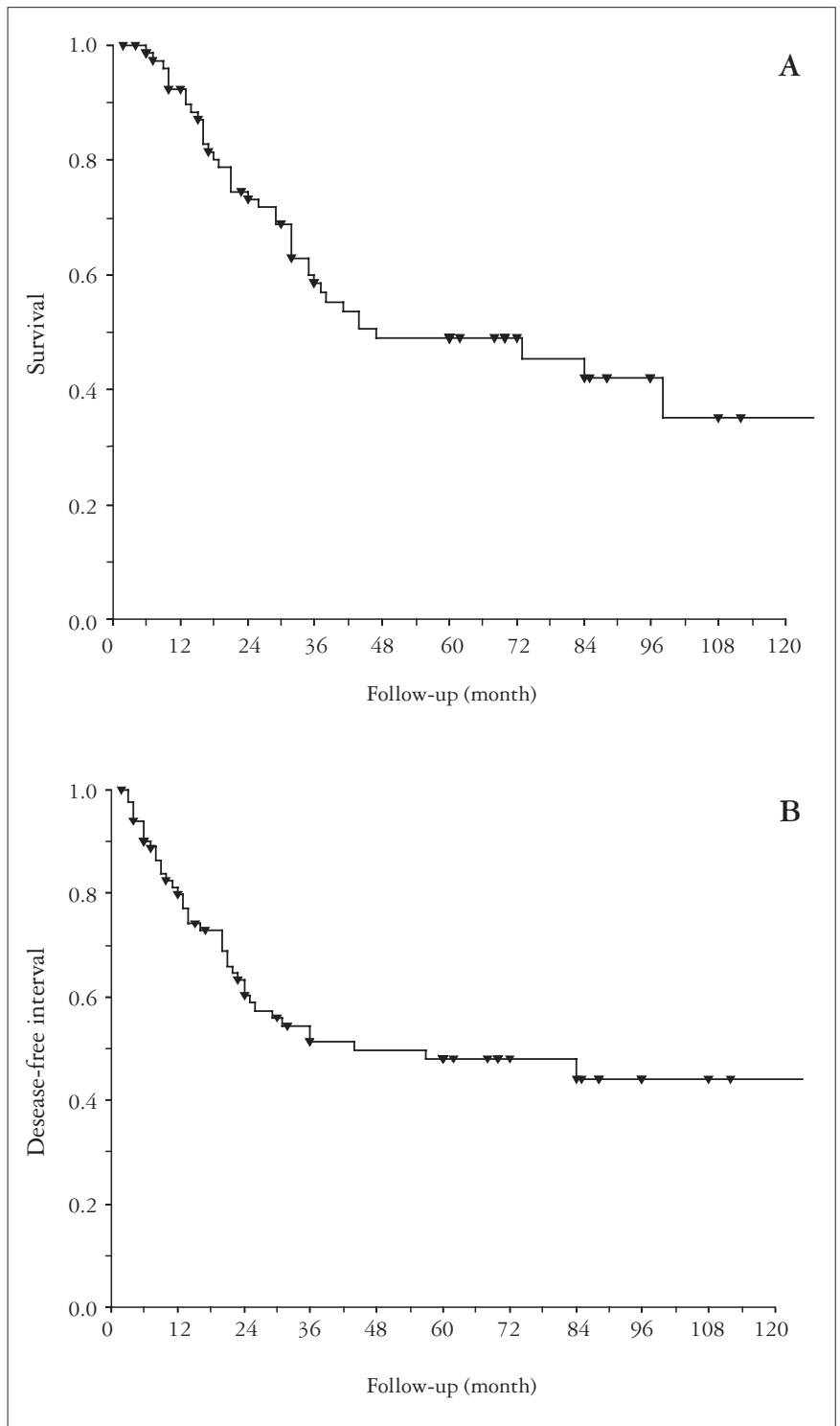

FIGURE 1 - Kaplan-Meier graphic representation of overall survival (A) and disease-free interval (B) during the follow-up period of 83 patients with rectal adenocarcinoma
There was no relationship between p53 and tumor size, symptoms, grade of differentiation, macroscopic tumor appearance, location and gender $(P>0.05)$. Table 3 shows the p53 protein prevalence in relation to the Astler-Coller classification, and Tables 4 and 5, demonstrate the association of p53, Astler-Coller classification and grade of differentiation with mortality, local recurrence, metastasis and overall recurrence.

TABLE $3-$ p53 and Astler-Coller classification

\begin{tabular}{lcc}
\hline \multirow{2}{*}{ Stage } & \multicolumn{2}{c}{$\mathrm{p} 53$ immunoexpression } \\
\cline { 2 - 3 } & $\mathrm{n}$ (negative $\mathrm{p} 53)$ & $\mathrm{n}$ (positive $\mathrm{p} 53)$ \\
\hline B1 & 11 & 10 \\
B2 & 11 & 5 \\
C1 & 6 & 4 \\
C2 & 19 & 17 \\
Total & $47(5.6 \%)$ & $36(4.4 \%)$
\end{tabular}

\section{DISCUSSION}

The prognosis of rectal adenocarcinoma has being determined through histologic stage at the moment of the operation, but some patients are still recurring despite potentially curative procedure and earlier pathologic staging ${ }^{(20,22)}$.

It has been proposed that genetic alterations acquired during tumor development may predict prognosis. In rectal cancer, the p53 mutation and allelic loss of the short arm of chromosome 17 lead to genetic alterations that inactivate the suppressor function of the p53, i.e., alterations of this gene leads to a non-functioning p53 protein. The association of the p53 through immunostaining study that evaluates the nuclear concentration of the mutated p 53 protein has been intensively assessed. The prevalence of the altered protein in rectal tumors varies from $40 \%$ to $60 \%$. In our trial we demonstrated p 53 positive expression in $43 \%$ of the cases.

The prognostic meaning of the p53 on the treatment of colorectal cancer remains uncertain. Many authors have found relation between positive $\mathrm{p} 53$ and survival improvement, such as BOSARI et al. ${ }^{(3)}$, SOONG et al. ${ }^{(26)}$, SUN et al..$^{(27)}$ and ZENG et al. ${ }^{(28)}$, while others haven failed to show the same relation ${ }^{(2,6,13,19,21)}$. DIEZ et al. ${ }^{(6)}$ and MAEDA et al. ${ }^{(16)}$ discovered a significant increase in immunopositive tumor and recurrence risk, while no other researchers could confirm these findings ${ }^{(6,8,16)}$.

Some authors believe that the best p53 evaluation would be through the study of the p 53 gene mutation (DNA sequence), and not through immunostaining evaluation of the p53 protein $^{(2,4,11,14)}$. KRESSENER et al. ${ }^{(14)}$ analyzed the DNA sequence and found mutations in $52 \%$ of the samples. The most important genetic alterations found were mutations, deletions and insertions, and $74 \%$ of these were located in the preserved p53 region. The immunostaining evaluation demonstrated $\mathrm{p} 53$ protein expression in $48 \%$ of the patients, and when compared to the DNA sequence, there was an agreement result of $74 \%$. Although the correlation was statistically significant, these two methods have had different sensitivity towards detecting p53 alterations. The evaluation of the DNA sequence predicted as compared to immunostaining method $(P=0.04)^{(14)}$. The parameters used to define the expression of the $\mathrm{p} 53$ protein, were the presence or absence of nuclear staining ${ }^{(14)}$. 
TABLE 4 - Analysis of clinical and pathologic features and mortality in patients with rectal adenocarcinoma

\begin{tabular}{|c|c|c|c|c|c|c|c|}
\hline \multirow{2}{*}{ Feature } & \multicolumn{4}{|c|}{ Bivariate analysis } & \multicolumn{3}{|c|}{ Multivariate analysis } \\
\hline & $\mathrm{n}$ & $\mathbf{R R}^{*}$ & CI95\% & $P$ & Rraj & $\mathrm{CI} 90 \%$ & $P$ \\
\hline Age (median) & 80 & 1.01 & 0.99 a 1.04 & 0.33 & - & & \\
\hline Male, gender & 81 & 1.63 & 0.86 a 3.05 & 0.13 & - & & \\
\hline TL & 75 & 1.66 & 0.58 a 4.70 & 0.34 & - & & \\
\hline Gross appearance & 75 & & & & & & \\
\hline Ulcerated & & 1.53 & 0.64 a 3.66 & 0.34 & - & & \\
\hline Infiltrating & & 1.08 & 0.53 a 2.18 & 0.83 & - & & \\
\hline Exophitic & & 1.12 & 0.49 a 2.55 & 0.78 & - & & \\
\hline Astler-Coller & 83 & & & & & & \\
\hline $\mathrm{B} 1 \dagger$ & & 1.00 & & & $1.00 \doteqdot$ & & \\
\hline B2 & & 2.24 & 0.60 a 8.37 & 0.23 & 2.65 & 0.84 a 8.37 & 0.17 \\
\hline $\mathrm{C} 1$ & & 5.29 & 1.62 a 17.22 & $<0.01 *$ & 4.83 & 1.65 a 14.10 & $0.02 *$ \\
\hline $\mathrm{C} 2$ & & 4.77 & 1.63 a 13.95 & $<0.01 *$ & 4.00 & 1.47 a 10.88 & $0.02 *$ \\
\hline Histology & 83 & & & & & & \\
\hline $\mathrm{W} \dagger$ & & 1.00 & & & $1.00 \ddagger$ & & \\
\hline $\mathrm{MD}$ & & 1.92 & 0.58 a 6.31 & 0.28 & 1.04 & 0.35 a 3.12 & 0.95 \\
\hline $\mathrm{U}$ & & 8.18 & 2.04 a 32.78 & $<0.01 *$ & 3.28 & 0.90 a 11.88 & 0.13 \\
\hline p53 & 83 & & & & & & \\
\hline$[+]>20 \%$ & & 2.27 & 1.18 a 4.36 & $0.01 *$ & $2.32 \ddagger$ & $1.34 \mathrm{a} 4.03$ & $0.01 *$ \\
\hline$[-] \leq 20 \% \dagger$ & & 1.00 & & & 1.00 & & \\
\hline
\end{tabular}

TABLE 5 - Immunoexpression of p53, Astler-Coller classification and grade of differentiation according to local recurrence and metastasis

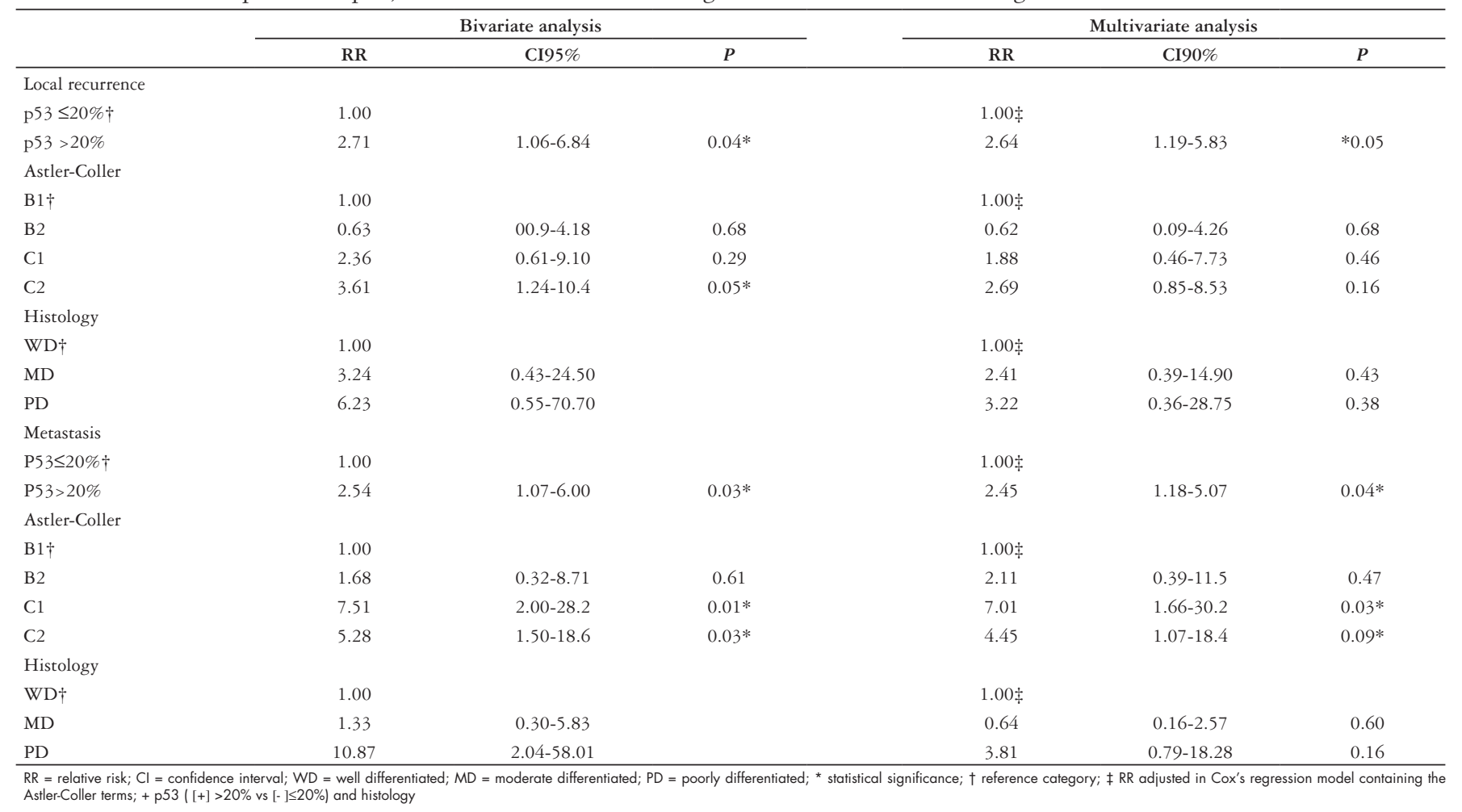


The lack of agreement among the studies may be attributed to a short follow-up period, different staging criteria and biases use on patient selection. Moreover, there is no consensus in the literature on criteria for interpreting immunostaining results. The amount of nuclear staining (expression) necessary to consider p 53 positive is still unclear. The use of a low cutoff leads to disparity and difficult the establishment of the $p 53$ protein expression either with prognosis, survival rate, loco-regional recurrence and metastasis. The great majority of the researchers use a cutoff of $5 \%$.

Another important fact is to consider colon and rectal cancer patients in the same group. GERVAZ et al. ${ }^{(9)}$ and DIEZ et al.(7) demonstrate that colon molecular biology differs from rectal molecular biology, specially regarding p 53 protein, that is why it is important to analyze only rectal cancer cases, as we did in this study.

In our study, we found no association between positive $\mathrm{p} 53$ and clinical and pathologic variables, such as gender, symptoms, location, size tumor macroscopic and gross appearance, circumferential tumor limit, which is in agreement with the literature. We also have found no association between these variables with recurrence and survival.
In these series we observed an association between positive p53, in a cutoff of $20 \%$ with death $(P=0.01)$, local recurrence $(P=0.04)$, distant metastasis $(P=0.03)$ and overall recurrence $(P=0.01)$. We also found an association between $\mathrm{p} 53$ positive and death $(0.01)$, local recurrence $(P=0.05)$, metastasis $(P=0.04)$ and overall recurrence $(P=0.01)$, when analysis was adjusted to Astler-Coller stage, grade of differentiation proven p53 as an independent prognostic factor.

\section{CONCLUSION}

Our analysis demonstrated that immunoexpression of the $\mathrm{p} 53$ protein is adequate to define prognosis in patients with rectal adenocarcinoma. The $\mathrm{p} 53$ protein is associated to established variables of worst diagnosis such as tumor stage $\mathrm{C} 1$ and $\mathrm{C} 2$, to slightly differentiated grade of differentiation degree as well as correlates an increased risk for recurrence and decreased survival, as demonstrated in the multivariate analysis. Therefore p53 immunoexpression can be considered as an independent prognostic factor in cancer treated by surgery.

Jurach MT, Meurer L, Moreira LF. Expressão da proteína p53 e relação clínico-patológica no adenocarcinoma de reto. Arq Gastroenterol. 2006;43(1):14-9.

RESUMO - Racional - p53 é um gene imunossupressor tumoral que tem sido implicado na patogênese de vários tumores, incluindo o câncer colorretal. Objetivo - Avaliar a expressão nuclear da proteína p53 com o valor prognóstico e correlacionar com variáveis clínico-patológicas e sobrevida. Material e Métodos - Foi realizado estudo imunoistoquímico da proteína p53 em 83 pacientes com diagnóstico de câncer retal com seguimento de, no mínimo, 5 anos. A expressão da proteína p53 foi associada com o estádio, com o grau histológico e com a recidiva. Resultados - A expressão nuclear da proteína p53 foi positiva em 36 (43.4\%) dos tumores. Encontrou-se associação entre p53 positivo e óbito, recidiva local, metástases à distância e recidiva total e, também, associação entre p53 e óbito, recidiva local, metástases e recidiva total, quando a análise foi ajustada para Astler-Coller e grau histológico. Conclusão - A expressão da proteína p53 tem demonstrado fator prognóstico independente.

DESCRITORES - Proteína p53. Neoplasias retais. Adenocarcinoma. 


\section{REFERENCES}

1. American Cancer Society. Cancer facts and figures. [cited 2002 Sept 30] Available from: http://www.cancer.org/statistcs.

2. Bell SM, Scott N, Cross D, Sagar P, Lewis FA, Blair GE, Taylor GR, Dixon MF, Quirke P. Prognostic value of $\mathrm{p} 53$ overexpression and c-ki-ras gene mutations in colorectal cancer. Gastroenterology. 1993;104:57-64.

3. Bosari S, Viale G, Bossi P. Cytoplasmic accumulation of $\mathrm{p} 53$ protein: an independent prognostic indicator in colorectal adenocarcinomas. J Natl Cancer Inst. 1994;86:681-7.

4. Bosari S, Viale G, Roncalli M, Graziani D, Borsani G, Lee AKC, Doggi G. p53 gene mutations, p54 protein accumulation and compartmentalization in colorectal adenocarcinoma. Am J Pathol. 1995;147:790-8.

5. The Centers for Disease Control and Prevention. Screening for colorectal cancer: United States, 1997. JAMA. 1999;281:1581-2.

6. Diez M, Medrano M, Muguerza JM, Ramos P, Hernandez P, Villeta R, Martin A, Noguerales F, Ruiz A, Granell J. Influence of tumor localization on the prognostic value of P53 protein in colorectal adenocarcinomas. Anticancer Res. 2000;20(5C):3907-12.

7. Diez M, Enriquez JM, Camunas J. Prediction of recurrence in B-C stages of colorectal cancer by $\mathrm{p} 53$ nuclear overexpression in comparison with standard pathological features. Eur J Surg Oncol. 1995;21:635-59

8. Gallego MG, Acenero MJ, Ortega S, Delgado AA, Cantero JL. Prognostic influence of p53 nuclear overexpression in colorectal carcinoma. Dis Colon Rectum. 2000;43:971-5.

9. Gervaz P, Bouzourene H, Cerottini JP, Chaubert P, Benhattar J, Secic M, Wexner S, Givve JC, Belin B. Dukes B colorectal cancer: distinct genetic categories and clinical outcome based on proximal or distal tumor location. Dis Colon Rectum. 2001;44:364-72.

10. Hertz REL, Deddish MR, Daye E. Value of examination in detecting cancer of the rectum and colon. Postgrad Med. 1960;27:290-4.

11. Kandioler D, Zwrtek R, Ludwig C, Janschek E, Ploner M, Hofbauer F, Kührer I, Kappel S, Wrba F, Horvath M, Karner J, Renner K, Bergmann M, Karner-Hhanusch J, Pötter R, Jakesz R, Teleky B, Herbst F. TP53 genotype but not p53 immunohistochemical result predicts response to preoperative short-term radiotherapy in rectal cancer. Ann Surg. 2002;235:493-8.

12. Khankhanian N, Mauligit GM, RusseL WO. Prognostic significance of vascular invasion in colorectal cancer of Dukes B class. Cancer. 1997;39:1195-200.

13. Kressner U, Lindmar G, Gerdin B. Immunohistological p53 staining is of limited value in the staging and prognostic prediction of colorectal cancer. Anticancer Res. 1996; $16: 951-7$

14. Kressner U, Inganäs M, Bydin S, Blikstad I, Pählman L, Glimelius B, Lindmark G. Prognostic value of p53 genetic changes in colorectal cancer. J Clin Oncol. 1999; 17:593-9
15. Leahy DT, Salman R, Mucahy, Sheahan K, O'Nonoghue DP, Parfrey NA. Prognostic significance of p53 abnormalities in colorectal carcinoma detected by PCR-SSP and immunohistochemical analysis. J Pathol. 1996;180:364-70.

16. Maeda K, Chung YS, Kang SM. Overexpression of cyclin D1 and p53 associated with disease recurrence in colorectal adenocarcinoma. Int J Cancer. 1997;74:310-5.

17. Miller SF, Knigth AR. The early detection of colorectal cancer. Cancer. 1997;40:945-9.

18. Moreira LF, Iwagaki H, Hizuta A, Sakagami K, Orita K. Outcome in patients with early colorectal carcinoma. Br J Surg. 1992;79:436-8.

19. Nathanson SD, Linden MD, Tender P. Relationship among p53, stage and prognosis of large bowel cancer. Dis Colon Rectum. 1994;37:527-34.

20. Olson RM, Perencevich NP, Malcom AW, Caffey JT, Wilson RE. Patterns of recurrence following curative resection of adenocarcinoma of the colon and rectum. Cancer 1980;45:2969-74

21. Pereira H, Silva S, Julião R, Garcia P, Perpétua F. Prognostic markers of colorectal cancer: expression of p53 and Bcl-2. World J Surg. 1997;21:210-3.

22. Ratto C, Sofo L, Ippoliti M, Merico M, Doglietto GB, Crucitti F. Prognostic factors in colorrectal cancer. Literature review for clinical application. Dis Colon Rectum. 1998;41:1033-49.

23. Ribeiro U, Alves VA, Souza PMB, Ribeiro AVS, Rawet V, Nonogaki S, Rodrigues JG, Habr-Gama A. Correlação das proteinas p53 e KI-67 com o prognóstico de pacientes com adenocarcinoma de reto distal. Rev Bras Coloproctol. 2000;20:248-56.

24. Rich T, Gunderson II, Lew R, Galdibini JJ, Cohen AM, Donalsdsib G. Patterns of recurrence of rectal cancer after potentially curative surgery. Cancer. 1983;52:1317-29.

25. Scwandner O, Schiedeck TH, Bruch HP. Apoptosis in rectal cancer: prognostic significance in comparison with clinical histopathologic, and immunohistochemical variables. Dis Colon Rectum. 2000;43:1227-36.

26. Soong R, Powell B, Elsaleh H, Gnanasampanthan G. Prognostic significance of TP53 gene mutation in 995 cases of colorectal carcinoma. Influence of tumour site stage, adjuvant chemotherapy and type of mutation. Eur J Cancer. 2000;36:2053-60.

27. Sun XF, Carstensen JM, Stal O. Prognostic significance of $\mathrm{p} 53$ expression in relation to DNA ploidy in colorectal adenocarcinoma. Virchows Arch A Pathol Anat Histopathol. 1993;423:443-8.

28. Zeng ZS, Sarkis AS, Zhang ZF. p53 nuclear overexpression: an independent predictor of survival in lymph node-positive colorectal cancer patients. J Clin Oncol. 1994; $12: 2043-50$. 